\title{
PERFIL DE BARBARA FREITAG
}

\section{Maria Francisca Pinheiro Coelho*}

Em 15 de abril de 2002, colegas, orientandos e ex-alunos de Barbara Freitag promoveram na Universidade de Brasília a jornada Itinerários de Barbara Freitag, que resultou no livro com mesmo nome. A coletânea é uma mescla de biografia e obra da homenageada, que participou ativamente do evento como debatedora de seu próprio pensamento. É o momento de Barbara por ela mesma. "Um debate acadêmico", segundo ela. Na verdade, um reencontro daqueles que tiveram o privilégio de conviver com ela.

Freitag emigrou com a família da Alemanha para o Brasil em 1948, com sete anos, e constituiu sua formação acadêmica no trânsito entre os dois países. Fez o curso primário e o secundário no Brasil e a graduação e a pós-graduação na Alemanha. No Brasil, estudou no Colégio de Itajubá, em Minas Gerais, e no Colégio Farroupilha e no Colégio Júlio de Castilhos, no Rio Grande do Sul. Voltou para a Alemanha em 1961 e cursou a graduação em Ciências Sociais na J. W. Goethe Universität/Frankfurt/M., o mestrado em Sociologia e Psicologia na Universidade Livre de Berlim e o doutorado na Universidade Técnica de Berlim.

Em Frankfurt, foi aluna de Adorno e Horkheimer por três semestres, a partir de 1962. Em 1967, defendeu sua tese de mestrado sobre Gilberto Freyre, Celso Furtado e Florestan Fernandes, e, em 1972, o doutorado sobre Política Educacional Brasileira. Tornou-se uma brasilianista e latino-amerecanista na Alemanha e também uma teórica da Escola de Frankfurt, tendo participado dos fervorosos embates na universidade em 1968. Depois que concluiu seu doutorado, recebeu um convite de Florestan Fernandes para lecionar no Brasil. Florestan foi o mediador de seu retorno ao país. Em várias visitas à

* Doutora em Sociologia, Pesquisadora Associada do Departamento de Sociologia da UnB. E-mail: coelho@unb.br 
Alemanha, ele havia insistido para que ela voltasse. O contrato com a Universidade de Brasília foi assinado em julho daquele ano. Ao encontro com Brasília e com a UnB somou-se um outro, com o filósofo e diplomata Sérgio Paulo Rouanet, com quem casou e tem uma filha, Adriana, de 29 anos.

A tese de doutorado foi publicada no livro Escola, Estado e Sociedade, que teve grande repercussão no país. O livro incomodou os militares, porque trazia uma abordagem transformadora da escola. Barbara mostrou que se a instituição escolar pode ser vista, segundo Althusser, como uma instância de reprodução da ideologia dominante, é mais do que isso, porque contribui para superar os déficits cognitivos no desenvolvimento psicogenético das crianças de classe baixa. A importância da escola foi analisada em outros livros, como o Diário de uma Alfabetizadora, no qual defendeu que a alfabetização não é apenas domínio de uma técnica, mas também condição necessária para que a pessoa utilize sua capacidade de pensar e para que veja o mundo segundo as categorias do pensamento lógico.

A formação intelectual de Barbara perpassa uma grade tríplice: a educação, a Psicologia e a Sociologia. Sua dimensão de educadora está estreitamente ligada aos estudos de Psicologia. Plenamente consciente da importância de integrar a teoria psicanalítica na reflexão sociológica, Barbara ministrou vários cursos sobre Freud. No campo da Psicologia dedicou-se, primordialmente, ao estudo da psicogênese piagetiana. Sua vocação de psicóloga aparece em pesquisas sobre a psicogênese infantil, baseadas na teoria de Piaget, a partir de estudos empíricos feitos em escolas e favelas paulistas. Nesses trabalhos, demonstrou que existe uma defasagem entre o desenvolvimento cognitivo e a competência moral e lingüística das crianças de classe baixa e as de classe média, entre as crianças escolarizadas e as nãoescolarizadas.

Contudo a dimensão central na formação intelectual de Barbara Freitag é a sociológica. A educação só pode ser entendida sobre o pano de fundo de tendências macrossociológicas. O estudo da psicogênese infantil tinha como objetivo proporcionar à criança 
instrumentos que permitissem superar bloqueios derivados das contradições de classe. Como socióloga, Barbara parte do princípio da unidade entre teoria e prática e por isso se dissocia da sociologia positivista que parte da existência de um observador neutro. Daí a importância que ela atribui ao marxismo, enquanto instância capaz de compreender e transformar o mundo, porém seu marxismo nada tem de ortodoxo.

Barbara tem afinidades especiais com a Escola de Frankfurt, que aborda a realidade a partir de um marxismo flexível, a teoria crítica, oposta a qualquer forma de dogmatismo. Dentro da Escola de Frankfurt, tem interesse particular por Habermas, que procura integrar os ideais emancipatórios do Iluminismo, inclusive os defendidos pelo marxismo, em um novo paradigma intersubjetivo e radicalmente democrático. Entre seus muitos livros, tem lugar de destaque Teoria Crítica: Ontem e Hoje, de 1994.

Nos últimos anos, Freitag tem-se dedicado ao tema das cidades, um campo específico e ao mesmo tempo múltiplo. Para ela, a cidade é mônada, no sentido de Walter Benjamin, metonímia, figura síntese da sociedade, para onde convergem todas as linhas de força do mundo moderno e pós-moderno. Cidade é história, geografia, arquitetura, pintura, literatura. Cidade é urbanidade, que vem de urbes, é política, cuja raiz é a polis, e é cidadania, cuja raiz é civitas. No tema da cidade, Barbara se encontrou, porque nele pôde juntar todos os fios de sua vida e de seu pensamento. Barbara é um pouco Berlim e um pouco Brasília, alemã e brasileira. Poderíamos chamá-la de cidadã do mundo. "Os conceitos políticos se baseiam na pluralidade, diversidade e limitações mútuas. Um cidadão é, por definição, um cidadão entre cidadãos de um país entre países", mencionou Hannah Arendt (1987, p. 75) em ensaio sobre Jaspers.

A identidade de Barbara com a UnB é tanta que os seus discípulos na instituição são chamados de "barbaretes". Ela esteve vinculada ao Departamento de Sociologia de 1972 a 2003, quando se aposentou e se tornou Pesquisadora Associada. É professora titular do Departamento desde 1988. Lecionou também em universidades 
estrangeiras, entre elas a Universidade Livre de Berlim. Foi professora visitante de várias universidades brasileiras: a Pontifícia Universidade Católica de São Paulo, em 1979; a Universidade Federal de Sergipe, em 1979-1980; a Universidade Federal de Minas Gerais, em 1985; a Universidade de São Paulo, em 1989; a Universidade Estadual de São Paulo, em 1990; a Universidade Federal da Bahia, em 1995; e a Universidade Estadual do Rio de Janeiro, em 1998-1999.

Ao todo Barbara Freitag escreveu 27 livros, de sua autoria ou por ela organizados, alguns publicados no exterior; 34 artigos publicados em coletâneas e revistas no exterior; 52 artigos publicados em coletâneas e revistas brasileiras; e diversos trabalhos de tradução, principalmente do alemão para o português.

Em 2005, ela foi homenageada duplamente pela UnB. Além do lançamento do livro Itinerários de Barbara Freitag, pela editora da universidade, o Instituto de Ciências Sociais encaminhou ao Conselho Universitário parecer solicitando que lhe fosse concedido o título de Professora Emérita. O título é conferido ao docente aposentado na Instituição, que tenha alcançado uma posição eminente em atividades universitárias. $\mathrm{O}$ sentimento dos que organizaram e participaram da jornada na UnB foi dos mais nobres: honrar uma colega pela sua dedicação integral à vocação acadêmica.

\section{Referências bibliográficas}

ARENDT, Hannah. Karl Jaspers: um cidadão do mundo? In:

Homens em tempos sombrios. São Paulo: Companhia das Letras, 1987.

ROUANET, Sérgio Paulo; SOUSA, Nair Heloísa Bicalho de; COELHO, Maria Francisca Pinheiro (Org.). Itinerários de Barbara Freitag. Brasília: Editora Universidade de Brasília, Finatec, 2005. 